Professional paper

\title{
ANALYSIS OF ERP SYSTEMS FROM THE PERSPECTIVE OF THE ENTERPRISES
}

\section{AZ INTEGRÁLT VÁLLALATIRÁNYÍTÁSI INFORMATIKAI RENDSZEREK VIZSGÁLATA AVÁLLALATOK SZEMSZÖGÉBŐL}

\author{
Viktor Nagy \\ Pécsi Tudományegyetem \\ Közgazdaságtudományi Kar \\ Regionális Politika és Gazdaságtan Doktori Iskola \\ Pécs, Magyarország \\ nviktore@gmail.com
}




\title{
AZ INTEGRÁLT VÁLLALATIRÁNYÍTÁSI INFORMATIKAI ENDSZEREK VIZSGÁLATA AVÁLLALATOK SZEMSZÖGÉBŐL
}

\section{ANALYSIS OF ERP SYSTEMS FROM THE PERSPECTIVE OF THE ENTERPRISES}

\author{
Kulcsszavak: informatikai vállalatirányítási rendszerek, ERP, SAP, IScala, Microsoft Dynamics Navision, \\ kiválasztás
}

\begin{abstract}
Kivonat
Az információ technológia fejlődésével párhuzamosan a hozzá használt eszközök, szoftverek is kiapadhatatlan tárházat kínálnak a felhasználók számára. Ez különösen igaz a gazdasági élet szereplőire, akik folyamatos versenyben állnak egymással és törekszenek nem csak a már megszerzett piaci pozíciójuk megtartására, de az újabb és újabb területek meghódítására is, amihez elengedhetetlen az előnyszerzés a vetélytársakkal szemben. A piaci előny megszerzéséhez azonban minden olyan információnak, adatnak és tudásnak a birtokában kell lenni, amelyekkel ez elérhető, egyébként életbe lép Lord Raleigh örökérvényủ mondata: „Az információ drága: csak a hiánya kerül többe."

Azt sem szabad azonban elfelejteni, hogy a maga a tudás és az információk, adatok halmaza, még nem helyez egyetlen gazdasági társaságot sem előnyösebb pozícióba a többiekhez képest. Ahhoz hogy mindebből előnyt kovácsoljon egy adott szervezet, az első feladat, a szelekció elvégzése. Ezt követően az értékes adatokat, információkat - amelyek segítik a vállalkozás érvényesítését, ambícióit - rendezni szükséges, amihez elengedhetetlen egy olyan rendszer, amely nem csak rendszerezi, leválogatja, megjeleníti a halmazban lévő adatokat, de össze is gyüjti, mind a vállalat belső, mind pedig külső környezetéből.

Ma már számtalan olyan rendszerrel találkozunk a piacon, amelyek mind megfelelnek annak az elvárásnak, hogy az adatokat és információkat összegyüjtsék és rendszerezzék. Ezek a rendszerek azonban egy sémára készülnek, van, amelyik többet nyújt, van, amelyik egy kicsivel kevesebbet, de felépítésben szinte nincs különbség, mivel standard vállalati folyamatokra épülnek. A gazdaság szereplői azonban eltérő méretủek és gazdasági rendszerüek, amiből egyenesen következik, hogy folyamataik is kisebb-nagyobb mértékben eltérnek, vagyis egy standard folyamatokra épülő rendszer nem tudja maradéktalanul kielégíteni igényeiket és nem képes olyan rugalmasan igazodni a vállalkozást érintő változásokhoz, mint ahogy maga a vállalkozás reagál a megváltozott gazdasági helyzetekre.

Jelen tanulmány célja összehasonlítani néhány jelentős, a piacon megtalálható ERP rendszert, az üzleti folyamatok változásának tekintetében egy részröl az integrált vállalatirányítási rendszerek tulajdonságainak, másrészről a gazdasági életben résztvevő felhasználók igényeinek szemszögéből.Hiszen más az igénye és elvárása egy KKV-nak vagy egy mikro vállalkozásnak, mint egy nagy- vagy multinacionális vállalatnak. Azonban minden gazdasági szereplỏnek fontos, hogy minél hatékonyabbá tegye vállalkozása folyamatait, azt pedig minél költséghatékonyabban tegye meg.
\end{abstract}

\footnotetext{
Abstract

In parallel with the development of information technology, software is used to provide an inexhaustible storehouse of users. This is especially true for the business actors, who are in constant competition with each other and strive not only to keep their acquired market position, but also to conquer new markets, which is essential for gaining an advantage over rivals. However, to obtain a competitive advantage, any information, data and knowledge must be in your possession, to achieve it. Otherwise enter into eternal sentence from Lord Raleigh: "The information is expensive: but a lack of it will cost more."

Nowadays, there are numerous systems on the market, all of them meet the requirements to collect and organize the data and create information. However, these systems generally are made on a similar schema, some of them provide more, while others a bit less, but there is almost no difference in their structure, since they are built on standard business processes.

However, it is important to note, that the knowledge and the information and data, does not put any single company to advantageous position compared to others. In order to benefit from that a particular company, the first task is to carry out the selection. Then your valuable data and information - which will help the company enforce ambitions - are necessary to settle, which requires a system that can not only organize data in a cluster, but also gathers it together, both from the internal and external environment of the company.
} 
However, the economic actors have a different sizes and economic systems, also their processes differ more or less, and therefore a system based on standard processes is unable to fully meet their needs and is not able to flexibly align to the business environment, such as the company responds to the changings of the economic situation.

This study aims to compare some leading ERP systems on the market, depending of the variable business processes, from the view of the ERP system properties, also on the other hand from the perspective of the needs of the participants, users in economic life. This is reasonable because of the different needs and expectations of an SME or a micro-enterprise, a large or multinational company. However, for every economic actor it is important to be cost effective, to make its business processes more efficient.

\section{BEVEZETÉS}

Egy vállalat-irányítási részrendszer, vagy a teljes komplexum megújítása során a döntéshozók több lehetőség közül választhatnak. Feltéve, hogy valamilyen informatikai rendszerük már évek óta létezik, cél lehet az integráció tényleges, teljes körű felépítése (ha kisebb részrendszereik elkülönülten működnek), de ugyanígy cél lehet új, fejlett szolgáltatások megjelenítése a piaci versenyben. Mindkét esetben egy informatikai projekt korrekt menedzselése szükséges, azaz az információ-feldolgozási igények pontos feltérképezése, ezek validálása, a megvalósíthatóság vizsgálata (az erőforrások függvényében), s az új rendszer kiválasztása, üzembeállítása. Mivel ma már elhanyagolható mértékű a teljesen egyedi, saját fejlesztésű informatikai megoldás (leginkább annak költségei és kockázatai miatt), így kézenfekvő annak vizsgálata, mennyiben felel meg a kész-félkész rendszerek kínálata az adott kategóriába tartózó szervezet számára. Informatikai rendszert nemigen lehet a „polcról levenni”, így a kiválasztási eljárás igencsak bonyolult: gondolni kell a meglévő rendszerre, a humán és más erőforrásokra, az adaptálási- bevezetési projekt nehézségeire - mindez nagyon kockázatossá és elhúzódóvá teszi ezeket a projekteket.

Jelen dolgozatban a problémakör egy részletét vizsgáljuk meg: vajon mennyiben felelnek meg a leggyakrabban alkalmazott ERP rendszerek a nagy számban működő KKV-k számára - s mit ajánlhatunk akkor, amikor egy versenytárgyalás során a kiválasztáshoz releváns paramétereket kell kiválasztani és értékelni.

\section{AZ ERP RENDSZEREK PIACA}

Az integrált informatikai vállalatirányítási rendszerek piacának kínálata több, mint elegendő lehetőséget, alternatívákat kínál. Ha körbetekintünk, több mint száz integrált ügyviteli és vállalatirányítási rendszert találunk csak a magyarországi piacon, és az ezzel foglalkozó vállalkozások közül egyre többen tekintik célcsoportnak a kis- és középvállalatokat is a 
potenciális nagyvállalatok mellett ${ }^{17}$. Ezzel egy időben a kis és közepes gyártó vállalatoknál az ERP rendszerek használata ugyanolyan kulcskérdéssé vált a sikerhez, mint más irányítási rendszerek megléte, mert a vállalatvezetők tisztában vannak azzal, hogy saját cégük is versenyképesebbé válhat a komplex, integrált informatikai rendszerek használatával. A KKVk esetében egyrészt a gazdasági világválság döbbentette rá a vezetést ennek igazságára, másrészt a millennium idején váltak ténylegesen hozzáférhetővé adott méretű és infrastruktúra-igényű, számukra is elérhető integrált csomagok.

Magyarországon még sok kis és középvállalat előtt áll ott az a feladat, hogy egy modern ERP rendszer bevezetésével javítsa versenyhelyzetét. Egyes statisztikák szerint (Rózsa, 2009) az ezredforduló után, 2004-ben az 50-250 fő közötti magyar KKV- k mindössze 20\%-a rendelkezett valamiféle, integráltnak mondható információs rendszerrel. A gazdaságfejlesztési EU-támogatásoknak köszönhetően ez a helyzet sokat javult, de a piac még mindig nagyon élénk.

A következőkben néhány vállalatirányítási informatikai rendszert fogok bemutatni és elemezni, amelyek Magyarországon a legelterjedtebbek, és amelyeket KKV-nak és nagyvállalatoknak egyaránt ajánlanak a szakemberek.

\section{1. táblázat. Néhány, a szakemberek által ajánlott ERP rendszer elsősorban KKV-k számára}

\begin{tabular}{|l|l|l|l|l|}
\hline $\begin{array}{l}\text { ERP } \\
\text { rendszer } \\
\text { neve }\end{array}$ & Mikrovállalkozás & Kisvállalkozás & Középvállalkozás & Nagyvállalat \\
\hline $\begin{array}{l}\text { MS } \\
\text { Dynamics } \\
\text { NAV }\end{array}$ & & ajánlott & ajánlott & \\
\hline Infosys & & & ajánlott & ajánlott \\
\hline iScala & ajánlott & ajánlott & ajánlott & ajánlott \\
\hline $\begin{array}{l}\text { SAP } \\
\text { Business } \\
\text { one }\end{array}$ & ajánlott & ajánlott & ajánlott 100 fóig & \\
\hline SAP R/3 & & & & \\
\hline Windirect & & ajánlott & ajánlott & ajánlott \\
\hline $\begin{array}{l}\text { Cegid } \\
\text { GPAO }\end{array}$ & & ajánlott & ajánlott & ajánlott \\
\hline
\end{tabular}

Forrás: Erdős Ferenc (2008): A KKV-k informatikai beruházásai és azok megtérülési lehetőségei Magyarországon Doktori értekezés és saját tapasztalatok alapján

\footnotetext{
${ }^{17}$ Az http://erp.lap.hu/website mintegy 100 ilyen rendszert sorol fel, s mind az „ERP”, integrált rendszer nevet viseli - nyilván megkönnyítve és ugyanakkor megnehezítve a választást...
} 
Az Erdős Ferenc által összeállított informatikai rendszerek listájából azokat választottam ki, amelyekkel valamilyen szinten az évek során kapcsolatba kerültem, illetve amelyeket tanulmányaim ideje alatt lehetőségem volt megismerni.

A kiválasztott informatikai rendszerek moduláris felépítésűek, mivel ez megkönnyíti a lépcsőzetes bevezetést, s igazodik a vállalati szervezetekhez, elkülönült funkciókhoz. Noha a modulok megnevezése hasonló, mégis szem előtt kell tartanunk, hogy az azonos elnevezésű modulok a rendszerekben, funkcionálisan és felépítésileg sem teljesen azonosak, így összevetésük mindenképpen ajánlatos. Vegyük példának a bér-és munkaügyi modult, ennél a modulnál a Microsoft Dynamics Navision és az SAP Business One rendszer esetében nem beszélhetünk teljes funkcionalitású modulról, hiszen a modul Human Resource Management része még nem felel meg minden vele szemben támasztott igénynek ${ }^{18}$. AWinDirect és a Cegid rendszer pedig egyáltalán nem tartalmaz ilyen modult.

A következőkben a kiválasztott rendszerek moduljait vizsgálom, majd a rendszerek tulajdonságait és funkcióit SWOT analízis segítségével elemzem.

\section{2. táblázat. A kiválasztott ERP rendszerek által lefedett folyamatok}

\begin{tabular}{|c|c|c|c|c|c|c|c|c|c|c|c|}
\hline 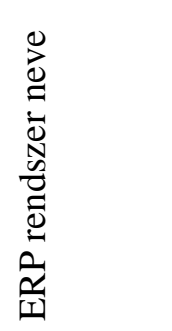 & 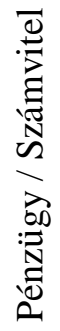 & 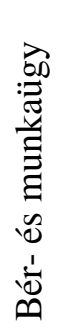 & 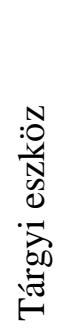 & 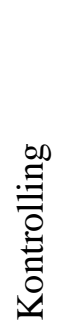 & $\frac{\mathscr{e}}{\mathscr{E}}$ & 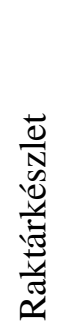 & $\begin{array}{l}\stackrel{\mathscr{N}}{N} \\
\stackrel{D}{N} \\
\infty \\
\infty\end{array}$ & 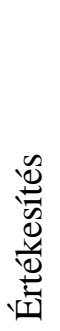 & 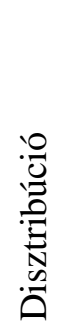 & 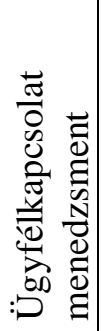 & 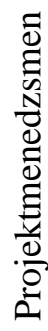 \\
\hline $\begin{array}{l}\text { MS } \\
\text { Dynamics } \\
\text { NAV }\end{array}$ & van & HR & van & van & van & van & van & van & van & van & van \\
\hline Infosys & van & van & van & van & van & van & van & van & nincs & nincs & van \\
\hline iScala & van & van & van & van & van & van & van & van & van & van & van \\
\hline $\begin{array}{l}\text { SAP } \\
\text { Business } \\
\text { One }\end{array}$ & van & HR & van & van & van & van & van & van & van & van & van \\
\hline SAP R/3 & van & van & van & van & van & van & van & van & van & van & van \\
\hline Windirect & van & nincs & van & van & van & van & van & van & van & van & van \\
\hline $\begin{array}{l}\text { Cegid } \\
\text { GPAO }\end{array}$ & van & nincs & van & van & van & van & van & van & nincs & van & van \\
\hline
\end{tabular}

Forrás: Erdős Ferenc (2008): A KKV-k informatikai beruházásai és azok megtérülési lehetőségei Magyarországon Doktori értekezés és saját tapasztalatok alapján

\footnotetext{
${ }^{18}$ A bér- és társadalombiztosítás nemzeti sajátosságait (s gyakori változását...) a nagy nemzetközi fejlesztők nem szeretik „lekövetni”, ezt inkább kiegészítő, helyi szoftverekre bízzák.
} 


\section{AZ SAP R/3 LEHETŐSÉGEI}

Az SAP R/3 rendszer moduláris felépítésű, az egyetlen kötelező elem a programcsomag magja, mely az adatbázisokat is tartalmazza. Az igényektől függően dönthető el, hogy a felhasználó vállalat az összes modult igénybe kívánja-e venni, vagy például csak a pénzügyi és projekt management modult egy banknál. A rendszert felépítő egyes modulokat az igényektől függően be lehet vezetni egyszerre egy lépésben, vagy egymás után, lépcsőzetesen. (J. A. Hernandez - J. K. Franklin - F. Martinez 2007)

\section{3. táblázat. Az SAP R/3 vállalatirányítási rendszer SWOT analízise}

\begin{tabular}{|c|c|}
\hline Erősségek & Gyengeségek \\
\hline $\begin{array}{l}\text { Adatok exportálhatósága Excel- } \\
\text { be }\end{array}$ & Magas licence költségek \\
\hline $\begin{array}{l}\text { Automatizáltan menthető } \\
\text { adatbázis }\end{array}$ & Nagyobb adatbeviteli igény \\
\hline Teljes ügyvitel lefedése & Nem annyira felhasználóbarát és intuitív \\
\hline Könnyű kezelhetőség & Testreszabása nehézkes \\
\hline $\begin{array}{l}\text { Kiváló készletgazdálkodási } \\
\text { képességek }\end{array}$ & $\begin{array}{l}\text { Az egymásra utaltságok, kölcsönhatások } \\
\text { nehezítik a menedzsment munkáját }\end{array}$ \\
\hline Naprakész könyvelés & Sok egyéni fejlesztés miatti lassú futás \\
\hline $\begin{array}{l}\text { Jobb döntéshozatal a naprakész } \\
\text { adatokra támaszkodva }\end{array}$ & Kényelmi funkciók hiánya \\
\hline $\begin{array}{l}\text { Nagyszámú előre definiált } \\
\text { lekérdezés }\end{array}$ & Nagy hardverigény \\
\hline Lehetőségek & Veszélyek \\
\hline $\begin{array}{l}\text { Használata a vállalkozás piaci } \\
\text { pozícióját erősítheti }\end{array}$ & $\begin{array}{l}\text { Jobb képességű, olcsóbb célzottan egy } \\
\text { területre megoldást kínáló szoftverek } \\
\text { jelenléte }\end{array}$ \\
\hline $\begin{array}{l}\text { Beépíthető a web alapú } \\
\text { SaaSmodelbe }\end{array}$ & $\begin{array}{l}\text { Az új piaci belépök a web } 2.0 \\
\text { segítségével a különböző területekre való } \\
\text { megoldásokat integrálhatják, egy } \\
\text { komplett ERP rendszer megvásárlása nem } \\
\text { szükséges }\end{array}$ \\
\hline $\begin{array}{l}\text { Vevői kapcsolatok kiszélesítése a } \\
\text { CRM által }\end{array}$ & $\begin{array}{l}\text { A vállalkozások szúkítik a technológiai, } \\
\text { vagy szoftver vásárlásaikat }\end{array}$ \\
\hline $\begin{array}{l}\text { Vevői elégedettség mérés, } \\
\text { véleményük felhasználása a } \\
\text { fejlesztésre }\end{array}$ & $\begin{array}{l}\text { Az SQL szerver rendelkezésre állása } \\
\text { kritikus }\end{array}$ \\
\hline Internetes ügyfélkapu kialakítás & $\begin{array}{l}\text { A lassú futás miatt megnövekedett } \\
\text { munkaerő szükséglet }\end{array}$ \\
\hline $\begin{array}{l}\text { EDI - elektronikus adatcsere } \\
\text { lehetőség }\end{array}$ & \\
\hline
\end{tabular}

Forrás: J. A. Hernandez - J. K. Franklin - F. Martinez 2007 alapján önálló munka. 
A táblázat adatai alapján jól látható, hogy az SAP legnagyobb előnye, hogy egy komplex, több modulból álló, kiforrott vállalatirányítási rendszer. A vállalkozás minden területét képes lefedni és azokat egy rendszerben, egy adatbázisban összefogni. Az adatok az adminisztrátoroknak köszönhetően naprakészek lehetnek, és az összegyüjtött naprakész adatokból a vállalkozás vezetése felelősségteljesebb döntéseket tud hozni, mint előtte, így a rendszer javíthatja az adott vállalkozás piaci pozícióját.

További előnye a rendszernek, hogy az adatok egyszerüen és gyorsan, minden egyéb plusz eszköz beiktatása nélkül exportálhatóak Excelbe, ami megkönnyíti a vállalkozások által igényelt különböző riportok és kimutatások elkészítését a megbízottak számára. A rendszer nagyszámú előre definiált lekérdezési lehetőségekkel is rendelkezik, ugyanakkor létrehozhatóak és menthetőek egyéni lekérdezések is. A rendszer modularitása segít, hogy a különböző területeken dolgozók könnyebben megtalálják, vagy rögzíthessék a területükhöz tartozó adatokat. Ezzel elkerülhető a többszörös adatbevitel a rendszerbe. Az adatbázis pedig automatizáltan menthető. A modulok közötti átjárhatóság jó.

Ugyanakkor a rendszernek vannak hátrányai is, amelyeket szintén figyelembe kell venni, amikor mérlegelünk. Ilyen a magas licence- és karbantartási költség, amit nyilván a piacvezető szerep és a felhalmozott tudásanyag indokol.A rendszernek nagy a hardver és adatbeviteli igénye más rendszerekhez képest, valamint a rendszer testreszabása nehézkes a standardizáltság miatt, és a sok egyéni fejlesztés lassítja a rendszer müködését, ami miatt elvesznek, hiányoznak a kényelmi funkciók és kevésbé felhasználóbarát, intuitív a program. Az egymásra utaltság és a kölcsönhatások miatt a menedzsment munkája némileg nehézkes a kinyerhető információk esetében, hiszen meg kell várniuk, amíg minden tranzakció befejeződik, amely egy információhoz kapcsolódik, hogy teljes képet kaphassanak az adott információról.

A rendszer használata erősítheti és növelheti az adott vállalkozás piaci pozícióját. Internetes ügyfélkapu kiépíthető a rendszer segítségével, amely segíti a partnerekkel való kommunikációt és a vevői megrendelések gyorsabb feldolgozását. Lehetővé teszi az EDI használatát, amely szintén segíti a vállalkozás folyamatait az igényekhez igazítani, mind a vevői, mind a beszállítói kapcsolatok szélesíthetőek, jobban testreszabhatóak.

A legnagyobb veszély a célzottan egy-egy területen megjelenő jobb képességű programok megjelenése, mivel, ezek integrálhatóak és így feleslegessé válik egy komplett ERP rendszer megvásárlása, olyan vállalkozások számára, akik nem tudják az SAP rendszer magas költségeit megfizetni. 
Mindent egybevetve az SAP alkalmas arra, hogy egy vállalkozás teljes ügyviteli folyamatait lefedje, segítse az adatok különböző területekről való összegyüjtését és feldolgozását. Ugyanakkor a standardizáltság miatt a testreszabása nehézkes a vállalkozás egyéni igényeinek megfelelően. Tehát inkább a vállalkozás folyamatait kell felülvizsgálni és a rendszerhez igazítani, ahhoz, hogy az az elvárásoknak megfelelően müködhessen.

\section{AZ iSCALA LEHETŐSÉGEI}

A Scala Business Solution által kifejlesztett alkalmazás a moduláris felépítésének és a kalibrálhatóságának köszönhetően maximálisan testreszabható rendszer. A rendszer teljesen integrált és más rendszerekhez is könnyedén kapcsolható. A rendszer skálázható, a felhasználó igényeire szabható, képes a vállalkozás méretéhez, növekedési üteméhez alkalmazkodni. Támogatja a vállalatok közötti online kommunikációt. Az alkalmazottak munkáját tovább könnyíti, hogy a rendszerhez a Microsoft Office alkalmazások integrálhatóak, így az adatok a megszokott irodai alkalmazásokon keresztül is közvetlenül elérhetőek. (http://www.piksys.hu)

\section{4. táblázat. Az iScala vállalatirányítási rendszer SWOT analízise}

\begin{tabular}{|c|c|}
\hline Erősségek & Gyengeségek \\
\hline $\begin{array}{l}\text { Kontrollálhatóság, tranzakciók } \\
\text { skálázhatósága, mobilitás }\end{array}$ & "Erőltetett" testreszabás \\
\hline Felhasználói felület tovább fejlesztése & $\begin{array}{l}\text { Nem felel meg minden tekintetben a } \\
\text { Magyarországi előírásoknak }\end{array}$ \\
\hline Üzleti tranzakció kezelő alrendszer & lassú bevezetés \\
\hline $\begin{array}{l}\text { Általános kitárolási modul, a } \\
\text { csomagolás és konténerezés segítésére }\end{array}$ & \\
\hline $\begin{array}{l}\text { Táblázatos vevői rendelés bevitel, } \\
\text { gyors rendelés bevitel }\end{array}$ & \\
\hline \multicolumn{2}{|l|}{ Bővített tranzakció kapacitás } \\
\hline \multicolumn{2}{|l|}{ Service connect fejlesztések } \\
\hline Lehetőségek & Veszélyek \\
\hline Jelentős verseny előny szerzése & $\begin{array}{l}\text { A jelentős fejlesztési és karbantartási } \\
\text { költségek likviditási problémákat } \\
\text { okozhatnak }\end{array}$ \\
\hline \multicolumn{2}{|l|}{ Újabb vevők megszerzése } \\
\hline $\begin{array}{l}\text { Egyszerü továbbfejleszthetőség, újabb } \\
\text { modulok bevezetésével }\end{array}$ & \\
\hline
\end{tabular}

Forrás: http://www.piksys.hu/termekek/scala/scala.htm alapján önálló munka 
A rendszer számos előnnyel rendelkezik, ezek közül a legfontosabb a tranzakciók skálázhatósága, a kontrollálhatóság és a mobilitás. A rendszer újdonsága és erőssége is egyben az üzleti tranzakció kezelő alrendszer, amely képes a vállalat üzleti folyamatait megfelelően kezelni.

Raktározás szempontjából a program erőssége a kitárolási modul, amely támogatja a csomagolást, a komissiózást és a konténerezést is. Vevőkapcsolati oldalról a megrendelések táblázatos bevitele nagy segítség az ügyintézők számára, mert így több rendelést és gyorsabban vihetnek be a rendszerbe, mintha egyesével kellene ezt megtenniük. A tranzakciós kapacitás pedig folyamatosan bővíthető.

Ebben a rendszerben is a standardizáltság miatt nehézségeket okozhat a testreszabás, amikor a vállalkozás folyamataihoz akarják igazítani a programot. A rendszer nem minden tekintetben felel meg a magyarországi elöírásoknak, de ez minden nemzetközi ERP rendszernél így van, de általában csak a pénzügyi és azzal kapcsolatos modulokat érinti, aminek oka abban rejlik, hogy az ezzel kapcsolatos szabályozás az országonként eltérő. Emiatt a rendszer bevezetése viszonylag lassú.

Az adatok egy adatbázisban történő tárolása hatékonyabb információ felhasználást tesz lehetővé, ami újabb partnereket, vevőket szerezhet a gazdasági társaság számára. Előnyt jelent az egyszerü továbbfejleszthetőség és az újabb modulok bevezetésének lehetősége.

Gondot okozhat viszont - mint minden ERP rendszernél -, a magas fejlesztési és karbantartási költség.

\section{A MICROSOFT DYNAMICS NAVISION LEHETŐSÉGEI}

Középméretű gazdasági társaságok részére készült a Microsoft Dynamics NAV, amely egyszerủen konfigurálható és könnyen használható, teljes körü vállalatirányítási informatikai támogatást biztosít a fejlesztők marketingje szerint. Ez az informatikai rendszer a SAP után a második leggyakrabban választott ERP rendszer a vállalkozások részéről.(http://www.microsoft.com/en-us/dynamics/default.aspx) 


\section{5. táblázat.A Microsoft Dynamics Navision vállalatirányítási rendszer SWOT analízise}

\begin{tabular}{|l|l|}
\hline Erősségek & Gyengeségek \\
\hline $\begin{array}{l}\text { Adatok exportálhatósága } \\
\text { Excel-be }\end{array}$ & Magas licence költségek \\
\hline $\begin{array}{l}\text { Automatizáltan menthető } \\
\text { adatbázis }\end{array}$ & Nagyobb adatbeviteli igény \\
\hline Teljes ügyvitel lefedése & Nem annyira felhasználóbarát és intuitív \\
\hline Könnyü kezelhetőség & Testreszabása nehézkes \\
\hline $\begin{array}{l}\text { Kiváló készletgazdálkodási } \\
\text { képességek }\end{array}$ & $\begin{array}{l}\text { Az egymásra utaltságok, kölcsönhatások } \\
\text { nehezítik a menedzsment munkáját }\end{array}$ \\
\hline Naprakész könyvelés & Sok egyéni fejlesztés miatti lassú futás \\
\hline $\begin{array}{l}\text { Jobb döntéshozatal a } \\
\text { naprakész adatokra } \\
\text { támaszkodva }\end{array}$ & $\begin{array}{l}\text { Nem felel meg minden tekintetben a } \\
\text { Magyarországi elöírásoknak }\end{array}$ \\
\hline $\begin{array}{l}\text { Táblázatos vevői rendelés } \\
\text { bevitel, gyors rendelés } \\
\text { bevitel }\end{array}$ & Nagy hardverigény \\
\hline Lehetőségek & Veszélyek \\
\hline $\begin{array}{l}\text { Használata a vállalkozás } \\
\text { piaci pozícióját erösítheti }\end{array}$ & $\begin{array}{l}\text { Jobb képességű, olcsóbb célzottan egy } \\
\text { területre megoldást kínáló szoftverek jelenléte }\end{array}$ \\
\hline $\begin{array}{l}\text { Egyszerü } \\
\text { továbbfejleszthetőség, újabb } \\
\text { modulok bevezetésével }\end{array}$ & $\begin{array}{l}\text { Az új piaci belépők a web 2.0 segítségével a } \\
\text { különbözö területekre való megoldásokat } \\
\text { integrálhatják, egy komplett ERP rendszer } \\
\text { megvásárlása nem szükséges }\end{array}$ \\
\hline $\begin{array}{l}\text { Vevői kapcsolatok } \\
\text { kiszélesítése a CRM által }\end{array}$ & $\begin{array}{l}\text { A vállalkozások szűkítik a technológiai, vagy } \\
\text { szoftver vásárlásaikat }\end{array}$ \\
\hline $\begin{array}{l}\text { vevői elégedettség mérés, } \\
\text { véleményük felhasználása a } \\
\text { fejlesztésre }\end{array}$ & $\begin{array}{l}\text { A lassú futás miatt megnövekedett munkaerő } \\
\text { szükséglet }\end{array}$ \\
\hline $\begin{array}{l}\text { A jelentős fejlesztési és karbantartási } \\
\text { költségek likvidítási problémákat okozhatnak }\end{array}$ \\
\hline
\end{tabular}

Forrás: http://www.microsoft.com és saját tapasztalatok alapján szerkesztett táblázat

A Microsoft Dynamics Navision-nak hasonlóak az előnyei és hátrányai, mint a SAP rendszernek. A rendszer nagy előnye, mely megkönnyíti a felhasználók munkáját, hogy az adatbázis könnyen kezelhető. Egyszerüen lehet az adatokat Excelbe mozgatnia rendszerből, amelyet azután fel tudnak használni különböző jelentések vagy bevallások készítésére.

Egyik nagy hátránya a magas licence költségek, amely alig marad el a SAP rendszer licence költségeitől. Nehézkes a testreszabása, hiszen standard rendszerről beszélünk, amelyet különböző paraméterezésekkel és fejlesztésekkel lehet az adott vállalkozás igényeihez igazítani, a sok fejlesztés pedig lassítja a rendszer futását. Itt is elmondható, hogy nem mindenben felel meg a magyarországi szabályozásnak, ami gyakran okoz problémát. 
Természetesen megvan benne a lehetőség, hogy használatával a gazdasági társaságot versenyelőnyhöz juttassa a piacon. A rendszer továbbfejleszthetősége nem túl bonyolult és bármikor bevezethetőek újabb modulok. A vevőkről és a beszállítókról gyűjtött adatokat is megfelelő módon tudják elemezni a rendszer segítségével és az így nyert információkat hasznosítani tudják a piaci versenyben.

A rendszer lassú futása miatti többlet munkaerő szükséglet, a karbantartási és fejlesztési költségek miatt esetleges likviditási problémák léphetnek fel.

\section{ZÁRADÉKOK}

Összegezve tehát kijelenthető, hogy noha a szállítók szeretik „késznek” reklámozni csomagjaikat, de bármelyik vállalatirányítási informatikai rendszert választja is egy szervezet, a bevezetésénél mindenképpen le kell írni, világosság kell tenni az információ-feldolgozási célokat, az érintett munkafolyamatokat, a felelősségi köröket, és a kulcsfelhasználókat.

Figyelembe kell venni a minőségirányítás alapelveit és a minőségirányítási kézikönyvben leírtakat, mert a minőségirányítás nagy befolyással bír a folyamatok által a vállalatirányítási informatikai rendszerre és ez kölcsönös, mivel a minőségbiztosítás munkáját is nagyban segíti és támogatja egy jól megválasztott integrált vállalatirányítási rendszer bevezetése és működtetése.

A KKV-k számaránya kb. 70-80\% a gazdálkodó szervezetek között, s méreteikben, erőforrásaikban nagymértékben eltérőek is lehetnek. Adott méret és tevékenységi szint felett azonban az ilyen rendszerek használata már elkerülhetetlen. Amennyiben egy vállalatnak van egy jól müködő minőségirányítási rendszere, akkor - a szabályozott folyamatok okán - sokkal egyszerübben és gyorsabban vezet be (adaptál) egy ilyen vállalatirányítási rendszert, s a kiválasztási folyamat (résztvevők, paraméterek, stb.) is sokkal megbízhatóbb lesz. Ha azonban csak néhány szétszórt informatikai alkalmazással rendelkeznek, akkor nehézségekbe ütközik az újítás, mert ha valami papíron nem müködik, az számítógépen, integrált rendszer segítségével sem fog müködni. A szoftver tehát nem minden, a mögöttes tudásra is szükség van. Ilyenkor elkerülhetetlen a célok átértékelése, a folyamatok újraszervezése, a szervezet átalakítása - mindehhez a hatalmas mennyiségü alkalmazási tapasztalatot felhalmozó ERP rendszerek sok segítséget tudnak nyújtani. 


\section{FELHASZNÁLT IRODALOM}

Erdős, F. (2008). A KKV-k informatikai beruházásai és azok megtérülési lehetôségei Magyarországon, Doktori értekezés, Széchenyi István Egyetem, Győr

Hernandez, J.A., Keogh, J., Martinez. F.F. (2007). SAP R/3 Kézikönyv. Panem Könyvkiadó Kft. 608 p. ISBN 978-9635454693

Az iScala rendszer ismertetése, http://www.piksys.hu

$\mathrm{Az}$ MS Navision rendszer ismertetése, http://www.microsoft.com/enus/dynamics/default.aspx

http://erp.lap.hu 